Sign Systems Studies 47(3/4), 2019, 400-419

\title{
General sociolinguistics, social semiotics and semiotics of culture - ex pluribus unum? Forty years after Language as Social Semiotic
}

\author{
Suren Zolyan ${ }^{1}$
}

\begin{abstract}
The birth of social semiotics is usually associated with the publication of Michael Halliday's book Language as Social Semiotic (1978). We try to draw attention to possible new developments in social semiotics, which still remain a potential transdisciplinary project for social sciences. In order to do this, we address the interrelation between sociolinguistics, social semiotics and the semiotics of culture. All of these describe mechanisms of meaning production and translation beyond linguistic structures. The differentiation between these workings is based on a distinction between various aspects of meaning production and communication and functional characteristics of goal setting. The complexity of these processes legitimates the complexity of methodology used to describe them. Interconnection between different domains and aspects may create synthetic methods based on the dynamic approach to meaning production and transmission.
\end{abstract}

Keywords: sociolinguistics; social semiotics; social semiotic; semiotics of culture; meaning production; textuality; Michael Halliday; Juri Lotman; Gunther Kress; Robert Hodge

1. In this paper, we do not intend to review research that has probably been influenced by Michael Halliday's outstanding work (Halliday 1978) and has emerged over the past forty years. Our objective is to draw attention to its new potential developments as we are still interested in identification of social and cultural mechanisms of meaning production. Firstly, we try to consider possible correlations between methods and approaches of sociolinguistics, social semiotics, and semiotics of culture. We propose to combine the latter two lines of research

\footnotetext{
1 (1) Institute for the Humanities, Im. Kant Baltic Federal University, Kaliningrad, Russia [Институт гуманитарных наук, Балтийский федеральный университет им. Им. Канта, Калининград, Россия]; (2) Institute of Philosophy, Sociology, and Law, National Academy of Sciences of the Republic of Armenia [Институт философии, социологии и права, Национальная Академия Наук Республики Армения]; e-mail: surenzolyan@gmail.com.
} 
and consider them as socio-cultural semiotics. For this, it is necessary to return to the origins of the issue and explicate what was actually understood by social semiotic in Halliday's works and how it was later transformed into social semiotics whether it is semiotics that studies social relations and institutions (including language) and describes them as sign systems, or sociolinguistics, that explores semiotic representations of social relationships in language. At the same time, it should be noted that the same issues are investigated by semiotics of culture, especially in the works of Juri Lotman and his followers.

From this point of view, we address the interrelation between sociolinguistics, social semiotics, and semiotics of culture. All of these describe mechanisms of meaning production and translation beyond linguistic and multimodal structures. We try to understand whether they are separate disciplines differing in their methods and object of research, or different domains of application of general semiotic approaches to non-linguistic objects, or different modes of description of the same semantic phenomena.

2. Current trends in sociolinguistics are no longer limited solely to linguistic structures: they examine multimodal discursive complexes formed by various semiotic codes. The shift of attention from socially determined and adapted linguistic variations to the functioning of language in society has led to a significant expansion of the scope of the problems and the arsenal of tools of modern sociolinguistics. With some reservations in mind, we still presume that social semiotics can be associated with three different sources: functional linguistics, discourse analysis, and the semiotics of culture. This initial heterogeneity provides a unique opportunity for interdisciplinary synthesis and creates a possibility for the unified theory of the heterogeneous manifestation of human creative and goal-setting activities. To a certain extent, after Halliday's seminal work a new discipline appeared - the synthesis of social semiotics and sociolinguistics. At the same time, as noted by Paul Cobley and Anti Randviir (2009), social semiotics was understood by scholars belonging to different traditions and schools in various ways and broken up into separate weakly related disciplines ${ }^{2}$.

2 Cobley and Randviir preferred to use another term, 'sociosemiotics': “Is it 'sociosemiotics' or is it 'social semiotics'? The former term tends to be dominant in the European tradition although, ironically, it echoes the predominantly Anglophone tradition (notwithstanding Gumperz, among others) of sociolinguistics. The latter tends to be associated with the AngloAustralian, Hallidayan perspective in communication and signstudy, although not exclusively so" (Cobley, Randviir 2009: 1). We do not intend to comment on this difference nor follow it, yet this distinction is important for other purposes, and our suggestion to consider them as absolute synonyms was strongly objected to by Robert Hodges (2019, personal com- 
A similar situation is connected with permanent differentiation within semiotics in general. Initially, at least in Charles Morris's project based on Charles Peirce's original ideas, the semiotic (sic!) was identified as an integrated science that can become an interface for various disciplines studying meaning and signs ${ }^{3}$. In spite of Morris's optimistic beliefs, semiotics of today is divided into a number of quasi-independent disciplines, and in some of them it is difficult to speak about meaning and sense. Thus, a whole range of different semiotics appeared, which were not associated with either social or cultural phenomena. As Susan Petrilli (2012: 458) noted in her article entitled "Social semiotics",

Semiotics is far broader than science that focuses on signs in the sphere of sociocultural life. Semiotics is not only anthroposemiotics but also endosemiotics (semiotics of cybernetic systems inside the organic body on the ontogenetic and phylogenetic levels), microsemiotics (the study of metabolism in unicellular life forms), mycosemiotics (semiotics of fungi), phytosemiotics (semiotics of plant life), zoosemiotics (semiotics of interactions among animals), machine semiotics (semiotics of sign processing machinery), environmental semiotics (the study of the interaction between the various species and environment).

However, another question arises: are these (1) different types of semiotics, opposed both by their object of research and description methods; or (2) different applications of the semiotic methods to various domains that naturally lead to the modification of descriptive and interpretative instruments. In accordance with the latter approach, a borderline can be drawn between sociolinguistics and social semiotics as a matter determined by the subject which is to be described either language as it is used in society (for sociolinguistics) or the organization of society described as a sign system (social semiotics). However, as we shall try to demonstrate below, the notion of a possible borderline between sociolinguistic and sociosemiotic approaches is more complicated; it can be understood in different ways and thus cause new differentiations (i.e. between social semiotic and social semiotics, and so on). A comparison with militant neighbouring states can be drawn: they constantly invade the territories of the neighbour and at the

munication): "'Absolute synonyms' is too strong. This important distinction should be reported and respected, even if you propose not to follow it (which is different, and more nuanced than proposing absolute synonymity)".

3 Cf: "Semiotic has for its goal a general theory of signs in all their forms and manifestations, whether in animals or men, whether normal or pathological, whether linguistic or nonlinguistic, whether personal or social. Semiotic is, thus an interdisciplinary enterprise. Part of the widespread interest in this area is motivated by the belief that higher-level sign processes (often called symbols) are of central importance in understanding man and his works" (Morris 1964: 1). 
same time are engaged in millimetre refinements of the borders between them. Therefore, the solution of permanent disputes may be the abolition of boundaries and their unification into (con)federation.

3. Language is a social institution and, at the same time, it is an instrument describing other social institutions. Another distinction can be associated with methods of description and analysis. Taking into account the fact that Saussurean semiotics can be considered as an application of linguistic methods of research to non-linguistic objects, the difference between sociolinguistics and social semiotics can also be reduced to the distinction between domains and objects of description.

Louis Hjelmslev pointed to this dualism of semiotics: semiotics can also be understood as a system of signs and sign systems operating in society and describing and regulating the internal organization of social relations. At the same time, semiotics can be considered as a scientific method describing signs and sign systems, including those mentioned above. Louis Hjelmslev argues that "in practice, language is semiotics into which all other semiotics could be translated - both all other languages and other possible semiotic structures" (Hjelmslev 1961[1943]: 109). This means that every entity endowed with some social significance is to be manifested in language and can be expressed through language. Hence, it can also be described by linguistic and semiotic means.

The functioning of social institutions appears as the processes of semiosis and communication, or as governed by specific rules of language games ${ }^{4}$. This makes it possible to combine linguistic meanings with social meanings by showing their interdependence, and at the same time differences in their manifestation. The former are manifested in language structures, and the latter - in social institutions. For instance, a constitution of a state is a verbal text as well as a set of rules for the functioning of a society, including the rules of communication between social institutions and citizens. These rules are not determined by this linguistic text, but they are described by it, and in this sense, we can assume that they are determined by it. Social semiotics acts as an intermediate mechanism that makes it possible to describe social relevance and functions of sociolinguistic entities (as it was shown in Searle 1995, 2008, and before it in Berger, Luckmann 1966).

At the same time, if we refer to issues of meaning and meaning production, we should take into consideration yet another semiotic domain - culture, and outline connections between sociolinguistics, social semiotics and the semiotics of culture. For us, semiotics of culture is not a complementary addition to social

4 Cf.: "I shall also call the whole, consisting of language and the actions into which it is woven, the 'language-game"' (Wittgenstein 1958: 5). 
semiotics, but rather a conjunction of another aspect within a single complex. Thus, sociolinguistics differs from anthropological linguistics not by its methods, but rather through the artificial differentiation of the same object of study. It seems that modern societies are "affiliated" with social semiotics and sociolinguistics, whereas others, exotic and archaic ones, are to be "supervised" by the semiotics of culture and/or anthropological linguistics. As one can foresee, in future, instead of two quasi-separate branches of semiotics, the socio-cultural semiotics may appear. It will describe socio-cultural entities, processes, and relations.

4. As was mentioned above, the origin of social semiotics is associated with the works of Michael Halliday. The newly-coined term 'social semiotic' was generally accepted after 1978 when he published his collection of articles. Later, the focus of social semiotics shifted from sociolinguistics to the study of multimodality and communication. However, the core function of language should not be disregarded: as most representations of human social activity (culture, history, literature, art, politics, law, etc.) are expressed in textual verbal forms, linguistic patterns of a textual organization have also been considered as a subject of social semiotic. ${ }^{5}$ At the same time, Halliday equated social reality entirely with culture: "A social reality (or 'a culture') is itself an edifice of meanings - a semiotic construct" (Halliday 1978: 2). Social semiotic has been understood as a characteristic of language interpreted within a certain sociocultural context, but not as a branch of semiotics (we discuss the distinction between 'semiotics' and 'semiotic' later).

This approach per se was outlined by Ludwig Wittgenstein who suggested that language be described not as a self-contained system, or even a system of systems, but rather as a set of heterogeneous language games and even "forms of life": "To imagine a language means to imagine a form of life" (Wittgenstein 1958: 19). With this approach in mind, language rules must correspond to contextual conditions and the speaker's intentions, and at the same time, depend on them. This mutual interdependence presumes diversity and flexibility, regarding both objectives, rules, and means of verbal communication.

The idea of language games became the basis of John Austin's performative, and was developed in John Searle's theories of speech acts and, with some reservations, in the Gricean maxims of conversational cooperation. At the same time, these conceptions can be connected with the direct or indirect influence of

5 Cf.: "[...] if we say that linguistic structure "reflects" social structure, we are really assigning to language a role that is too passive [...]. Rather we should say that linguistic structure is the realization of social structure, actively symbolizing it in a process of mutual creativity. Because it stands as a metaphor for society, language has the property of not only transmitting the social order but also maintaining and potentially modifying it" (Halliday 1978: 186). 
Bronislaw Malinowski’s contextual theory of meaning (Malinowski 1923, 1935). Though Malinowski is better known as an anthropologist, not as a linguist, he can also be considered as the founder of the modern functional approach to language, in which language and linguistic behaviour are seen as tools of social interaction, or a mode of collective action:

Language, in its primitive function, to be regarded as a mode of action, rather than as a countersign of thought [...]. We have to realize that language originally, among primitive, non-civilized peoples was never used as a mere mirror of reflected thought In its primitive uses, language functions as a link in concerted human activity, as a piece of human behavior. It is a mode of action and not an instrument of reflection. (Malinowski 1923: 296, 312)

"Doing things by the words" was identified by Malinowski as a dominant language function, although he could not use this famous motto coined latter. Malinowski had an influence on the peculiar approach of the London School and especially on the works of John Rupert Firth (1957) and then - Michael Halliday.

5. Contrary to existing views, the term 'social semiotic' first appeared in Halliday 1975, where social semiotic was understood as a 'general sociolinguistic theory' 6 Nevertheless, very soon the subtitle was slightly changed, and in 1978, the book Language as Social Semiotic: The Social Interpretation of Language and Meaning appeared. Instead of a general sociolinguistic theory, Halliday suggested another approach: a new viewpoint to describe language and meaning, rather than proposing a general theory - the new viewpoint of interpretation of linguistic data. To some extent, it was a repetition of Malinowski's social contextualism, but it was strengthened by instruments of semiotics of language and textlinguistics. This made it possible to enrich the scientific approaches of the time significantly. The newly-coined term 'social semiotic' (sometimes, Halliday spelled it as 'sociosemiotic') became generally accepted after 1978, although in Halliday's conception the term rather referred to sociolinguistics than to semiotics. Sooner, it was a semiotic approach to sociolinguistics than the emergence of a new branch of semiotics. The final statements of Halliday's article "Language as social semiotic" 7 outline the limits of this approach as a mode of interpretation.

6 This paper of 1975 was reprinted in Halliday (2009) with the note: "Language as Social Semiotics [sic! - in spite of its title that uses semiotic] from Adam Makkai and Valerie Becker Makkai (eds.), The First LACUS Forum, 17-46, (1975). The first publication, unfortunately, was not available for us.

7 Cf.: "I have been attempting here to interrelate the various components of the sociolinguistic universe, with special reference to the place of language within it. It is for this reason 
However, at the same time the mode of interpretation was expanded on social processes and human interaction, and notions not ordinary in linguistics such as 'semantics of social class', 'power system', and so on, undoubtedly promoted the ways to consider these social entities as specific sign systems.

6. It is not a widely known fact that the term 'social semiotics' ('соииальная семиотика' in Russian) was independently coined by Juri Lotman (Lotman $1975,1976,1977)$ nearly at the same time as Halliday created it. A common linguistic background for both approaches can be found in Malinowski's theories of contextualism and functionalism. However, Lotman and other researchers of the Tartu-Moscow School concentrated more on the semiotics of culture. Thus, social relationships were considered as a component of culture and, later, of the semiosphere ${ }^{8}$. Lotman's version of social semiotics outlined the basic principles of a new theory, in which not only verbal or non-verbal textual messages, but also social actions and behavioural patterns can be considered as semiotic phenomena and languages. This approach makes it possible to link categories of social semiotics to the basic concepts of theoretical sociology, such as social action, meaning, and communication. Neverthless, in the works of Lotman and other representatives of the Tartu-Moscow School, the notion of 'social semiotics' was not developed further until the 1990s (for more details see Zolyan 2017).

Still, there is an important difference between the Tartu-Moscow and the London Schools and approaches. Social relations, according to Lotman, are an object of research by semiotics of culture. Social semiotics is rather regarded as an object of analysis, and is understood as a system of actual relations in society but not as a method of research. In Halliday's view, social semiotics is represented in language and through language. Lotman suggested another approach: instead of analysing semiotic representation of social relations he preferred to view these representations and relations only as a part of symbolic mechanisms regulating

that I have the mode of interpretation of the social system as a semiotic and stressed the systemic aspects of it: the concept of the system itself, and the concept of function within a system. A 'sociosemiotic' perspective implies an interpretation of the shifts, the irregularities, the disharmonies and the tensions that characterize human interaction and social processes. It attempts to explain the semiotic of the social structure, in its aspects both of persistence and of change including the semantics of social class, of the power system, of hierarchy and of social conflict. It attempts to explain the linguistic processes whereby the members construct the social semiotic, whereby social reality is shaped, constrained and modified" (Halliday 1978: 127).

8 "All semiotic space may be regarded as a unified mechanism (if not organism) [...]. Without the semiosphere, language not only does not function, it does not exist. The different substructures of the semiosphere are linked in their interaction and cannot function without the support of each other" (Lotman 2005[1984]: 208). 
communication and behaviour. These mechanisms are expressed in norms, prohibitions, evaluations, patterns and rules of social behaviour. Language with its norms and regulations is only one of the forms of their expression and manifestation. Lotman prefers to consider behaviour as a language regulated through its own rules of semiosis and even "grammars" and "texts":

From the semiotic point of view, culture appears as a certain continuum of languages, used by the self-conscious cognition of man, and actions, both verbal and performed with the help of various deeds, can be interpreted as texts in some languages. Understanding the meaning of people's historical actions, their behaviour and their writings means mastering the languages of their cultures. (Lotman 2008[1988]: 510)

For Lotman, the concept of culture "is interpreted in a limited sense as systems for the preservation, transmission, and creation of new varieties of information" (Lotman 2013: 53). So it seems quite natural that, from this point of view, culture may be represented as a continuum (or even the Universum) of languages and semiotic systems, including social semiotics as one of its regulating subsystems. It should also be noted that the Russian expression 'социальная семиотика' can be translated not only as 'social semiotics', but also as 'social semiotic': Lotman referred to semiotic systems and entities existing in the Russian society in the 19th century. Thus, his understanding of this term can, in some respects, be equated with Halliday's meaning of 'sociosemiotic' when he used it in an expanded sense, but with some reservations. Halliday identified the 'sociosemiotic' as "the mode of interpretation of the social system as a semiotic" (Halliday 1978: 126); Lotman's view is more rooted in ontological aspects of social semiotic/semiotics: he addressed semiotic relations, objects and features which are inherent in society; this is sooner a mode of self-identification and self-interpretation of social actors and society than a mode of their description.

7. The proper institutionalization of social semiotics and an attempt to differentiate it from sociolinguistics took place ten years later - after the publication of the book signified a crucial change of paradigm. Now this work is usually viewed as a continuation of Halliday's ideas. However, quite another vision of the subject of social semiotics was given in it. The method of functional analysis in the spirit of the London School was combined (or even replaced) with Marxism-oriented critical discourse analysis. Social Semiotics develops the ideas of Language as Ideology which had been published earlier by the same authors (Hodge, Kress 1979) and in which, in line with Marx's notion, ideology is understood as "a false 
consciousness" and language as "a practical consciousness" (Hodge, Kress 1979: 5-6). The Soviet dissident scholars Mikhail Bakhtin and Valentin Voloshinov (Voloshinov 1973) (but not Halliday) were mentioned as the "founding fathers" of social semiotics. Most importantly, social semiotics was proclaimed as a new type of semiotics based on postulates, each of which is directly opposed to the positions of the Saussurean semiotic conception. The term 'social' was opposed to the abstract consideration of semiotic messages as immanent structures: "Unlike the existing semiotics, which says signs are used - a notion taken over from Saussure - we said signs are made and signs, therefore, are always newly made" (Lindstrand 2008: 62-63). Multimodality appears as a natural consequence of such approaches, due to the fact that not only verbal texts but also other cultural and social artefacts formed by various semiotic codes that become the object of analysis. At the same time, the term 'social' was understood in its broadest sense, covering all the processes and products of the human semiosis:

Social semiotics is primarily concerned with human semiosis as an inherently social phenomenon in its sources, functions, contexts and effects. It is also concerned with the social meanings constructed through semiotic texts and semiotic practices. Social semiotics studies all human semiotic systems, since all these are intrinsically social in their conditions and content. (Hodge, Kress 1988: 262)

This was a perspective opposite to the approaches of the Tartu-Moscow School: as could be presumed, cultural phenomena were considered as intrinsically social in their conditions and content, thus semiotics of culture was also interpreted as a branch of the newly emerged social semiotics.

8. One can see that the differences between the above-mentioned approaches are substantial, but not contradictory. These can be reconciled within a more general frame of reference. Social objects and relations are considered by semiotics of culture, and, on the contrary, social semiotics studies mechanisms and texts related to culture. This controversy has its inner logic and justification. As Niklas Luhmann (2013[2002]: 27] mentioned regarding Thomas Parsons's theory of society,

[...] this is quite an unusual distinction [between culture and social systems S.Z.], because it is almost impossible to imagine social operations that are clearly oriented to exclusively cultural aspects, and, on the other hand, it is hardly possible to imagine social actions that would have been done without this patternmaintenance function. 
Very similar ideas were expressed by Halliday, who actually understood 'cultural' as 'social' and 'social' as 'cultural':

From this perspective, language is one of the semiotic systems that constitute culture. One that is distinctive in that it also serves as an encoding system of many (though not all) of the others. This in summary terms is what is intended by the formulation "language as social semiotic". It means interpreting language within a sociocultural context, in which the culture itself is interpreted in semiotic terms as an information system. (Halliday 1978: 2)

So there is an approach in which a natural nexus between various manifestations of meaning, language, and culture can be established. Social relations and institutions are types "of a particular interpretation", but not separate domains. This conception can be associated with the theory of meaning in social sciences. Thus, Max Weber introduced the concept of meaning as a key for "understanding" sociology. For him, the primary objective for a sociological theory is to understand "the meaning of behaviour": "Action is social insofar as, by virtue of the subjective meaning attached to it by the acting individual (or individuals), it takes account of the behavior of others and is thereby oriented in its course" (Weber 1964[1947]: 88). Based on this definition, one can suggest the transdisciplinary symbiosis around the study of the problem of meaning and its manifestation in linguistic forms. However, Weber never paid any attention to linguistic forms of meaning (he even did not mention linguistics among the disciplines studying meaning!).

Meanwhile, as not only semiotics and linguistics, but also modern sociology insist, meaning cannot exist as something isolated - it is always manifested through some ensemble of symbols and discourses. The socio-semiotic view on language "as a social semiotic" provides an opportunity to connect the linguistic approach to social meaning with the basic ideas of interpretative sociology where the concept of meaning is crucial and especially with Luhmann's systemic theory: "Meaning is co-present as a reference to the world in everything that is actualized... Society is a meaning constituting system" (Luhmann 2012 [1997]: 21). Luhmann's operational concept of meaning ${ }^{9}$ creates a template to correlate the different "meanings of meaning": meaning as a semiotic relation between signifier and signified $v s$ meaning as an aim or a causal relation between different events all these understandings are caused by different but interconnected permanent processes of self-referential meaning production.

9 Cf: "Each meaning thus means itself and other things [...]. Meaning exists only as a meaning of operation using it, and hence only at the moment in which operations determine it" (Luhmann 2012[1997]: 20, 19). 
9. All the above-mentioned conceptions describe different yet inseparable aspects of human activities and communication. As Robert Hodges mentioned in a comment on this passage,

Within this wider framework of multiple intersections of multiple competing and complementary traditions, there is a particular value at this time in exploring two specific traditions where the connections and difference have not been examined to the extent they warrant: the Russian semiotics of culture and the AngloAmerican social semiotics. (Hodge 2019, personal communication)

The difference between them can be based on the distinction between various aspects of meaning production and communication and the functional areas of goal setting. The complexity of these processes predetermines the complexity of methodology for their description. The interconnection between different domains and methodologies may create synthetic methods. In addition to the complexity determined by the subject itself, this case demonstrates how the traditions of the structuralist Tartu-Moscow School of Semiotics, the London functional linguistics, and the German sociological thought are intertwined. However, at the same time, this is an example of ignoring each other, since these schools speak different dialects of the Humanities and do not make any significant efforts to hear and translate each other. As it seems, this is but a first attempt to bring them together and reconcile the notion of meaning in the interpretative sociology with linguistic meaning.

To conclude, we outline the main points that are based on the ideas of social semiotic/semiotics expressed more than forty and thirty years ago and which can be developed as a new paradigm for describing the processes of semiosis and communication.

(a) Communication is not limited to operations on signs and texts. It is also determined by patterns of behaviour and interpersonal interaction. This semantic conception is a synthesis of social semiotics with interpretative sociology, assigning meaning to complexes of verbal and nonverbal actions. Not only these, but all other disciplines in the humanities (as well as political science, sociology, historiography, esp. the philosophy of history, cultural studies, etc.) are oriented towards studying such processes as the generation, representation and identification of meaning in its ordered (text-based) forms.

(b) Meaning production should be considered as a juxtaposition of linguistic and extralinguistic systemic factors in the process of communication and social 
interaction. The semantics of linguistic structures is generated as a dynamic context-dependent derivative from linguistic, social, cognitive, and referential characteristics. Semantic interpretation is not limited by operations on lexemes and sentences, but is based on conventional frames and models of social behaviour and interaction. This can be described as a mechanism for correlating multimodal texts and sets of actual and latent contexts with the sets of their possible values (interpretations, worlds, and texts) and discourses (language games). According to this approach, it becomes possible to relate logical and semantic characteristics with cognitive ones. The semantics of text appears as a dynamic context-dependent value, a function of its linguistic, cognitive, and referential variables. ${ }^{10}$ The dynamic approach requires reflecting on the capacity of text to generate new values within the processes of text-production, processing, and functioning. Verbalization and construction of mental representations are considered as mutually influencing multi-stage processes. Understanding is not limited to operations on signs and texts; it is governed by patterns of behaviour and interpersonal interaction. A multimodal text, not a sign, is the key element of communication and the main object and instrument of a consistent process of creation-transfer-preservation-transformation of information.

(c) This theory can become the basis for social semiotics dealing with not only signs and texts, but also with semantic and textual aspects of social behaviour and its entities (events, deeds, claims, rituals, customs, etc.). This new version of semiotics may be a synthesis of social semiotics with interpretative sociology, assigning meaning to complexes of verbal and nonverbal actions. The apparatus of the semiotics of natural language can be used as a (meta-)language as it provides possibilities for mutually acceptable translation between theories developed in various fields of humanitarian knowledge: slightly paraphrasing the words of Louis Hjelmslev mentioned above, it can be argued that the semiotic, semiotics and meta-semiotics of natural language can be used as a meta-language into

10 Cf.: "Obviously one cannot quarrel with the use of the term "text" to refer to a string of sentences, that realize a text, but it is important to stress that the sentences are, in fact, the realization of text rather that constituting the text itself [...]. In its most general significance, a text is a sociological event, a semiotic encounter through which the meanings that constitute the social system are exchanged. The individual member is, by virtue of his membership, a 'meaner', one who means. By this act of meaning, and those of other individual meaners, the social reality is created, maintained in good order, and continuously shaped and modified [...]. Text is the primary channel for transmission of culture, and it is this aspect - text as the semantic process of social dynamics - that more than anything else shaped the semantic system" (Halliday 1978: 135, 139, 141). 
which all other semiotics and meta-semiotics (cultural and social among them) could be translated.

\section{Afterword}

The author had a unique opportunity to discuss this article with its main actants, Gunther Kress, and Robert Hodge. During our meetings in 2018, both of them demonstrated a great interest in the approaches of the Tartu-Moscow School of Semiotics and discussed possible ways of its syntheses with Halliday's functional systemic theory of language. They considered social semiotics in dynamics and were interested in reviewing the new potential developments. In part, this discussion took place during a conference held at the Immanuel Kant Baltic Federal University ${ }^{11}$. The event was planned in association with the 40th anniversary of the release of Michael Halliday's seminal book, but as the conference preparations were in progress, the sad message of the death of Michael Halliday arrived, and the organizers decided to dedicate this event to his memory. The conference was conceived as a summing up of achievements, and as a discussion of further prospects. Gunther Kress and Robert Hodge were eager to implement this idea; as they presented their reports (Robert Hodge joined us on Skype), we agreed on the continuation of the main idea: the further ways of semiotics were seen as a transdisciplinary synthesis of the humanities. These discussions became an impetus both for writing this article as well as asking comments on it from Kress and Hodge.

Both Kress and Hodge had mentioned the necessity for new approaches and Kress had even been preparing a new book on the subject. He sent me two letters and an unpublished article in which, as he mentioned in an accompanying note, "you may find some affinities with the ideas you set out in your paper" (Kress, letter to S. Z., 27 April 2019). Sadly, Gunther Kress can no longer participate in the discussion; however, I would like to cite excerpts from his two letters and the manuscript sent to me. I think these passages demonstrate what he saw as social semiotics can serve as an effective approach applicable to different semiotic phenomena as it is "relatively free from baggage that other approaches carry around with them" (Kress, letter to S. Z., 30 April 2019).

In his still unpublished paper on translation, a passage can be found which could be seen as a principal foundation for the conjunction of his vision of social meaning production and Lotman's conception of 'self-growing Logos':

11 Social Science as Social Semiotics: Bridging Theories, Methods, and Practices. In memoriam M. A. K. Halliday. 25-27 September 2018. Immanuel Kant Baltic Federal University, Kaliningrad, Russia. 
Social Semiotics, the theory proposed here to deal with "the issue at hand", has "process" in the form of ceaseless semiosis at its core. The three central issues in sign-making - interest, criteriality, and the newly made motivated sign - are crucial in naming, and in doing away with the misleading view of the "transport of meaning". As the choice of an apt signifier for a signified is based on the interest of the sign-maker, each sign that has been made leads to a transformation of the signifier that was used. From that perspective there is no possibility of stable meanings. As the signified is shaped by the always varying conditions of each prompt and of what is seen as criterial at that point, there is no stability of the signified. The condition of the always new making of the sign, both in the initial sign-maker's production and in the interpretation by the addressee, means that the idea of stability in semiosis is unfounded and a problematic distraction. (Kress, manuscript)

In response to my comments on his ideas about translation theory, he informed me about his new ambitious prospects of outlining a new book on Social Semiotics.

I'm happy that you found the paper on translation interesting. I do think, even from the quickest reading of the materials that you have sent me, that there is a lot of commonality between "my" notion of Soc Sem, and stuff in the article. As I mentioned, I am not at all competent / knowledgeable in Translation theory. I do have a strong sense that many of the problems I see discussed, from my very marginal position and reading, can be provided with satisfactory accounts in Social Semiotics: relatively free from baggage that other approaches carry around with them. When I have the outline for the new book on Social Semiotics that I want to do, I will send it to you for your comments. (Kress, letter to S. Z., 30 April 2019)

Of course, one can only speculate why Gunther Kress found it necessary to write a new book on social semiotics. Still, one thing is certain - he saw new ways of developing the discipline. His memory might be honoured by continuing a dialogue with him - taking from him the ability to deal with issues without the baggage of old approaches and at the same time carefully exploring all alternative solutions.

\section{$\mathbf{x}$}

Robert Hodge kindly made a number of remarks on the text, which I tried to take into account. He also proposed a detailed commentary that makes it possible to understand better both the intellectual roots of social semiotics and its possible development with regard to transdisciplinary synthesis. Hodge was particularly 
interested in the legacy of Juri Lotman and the Tartu-Moscow School, expressing regret that he, like his Western colleagues, was not sufficiently familiar with their approaches. In addition to the comments, he expressed a number of ideas that constitute an original contribution and should be presented in their entirety. Thus, with Robert Hodge's permission, I shall cite two lengthy passages. One of them characterizes Hodge's vision of the issues I touched upon, as he makes a number of important observations and clarifications.

You bring in Juri Lotman late. I would have liked to see him earlier and more of him. Anglo- and European readers still don't know his work nearly as well as they ought to, in my view, and your knowledgeable contribution would be welcome in that world, and I imagine that his work still isn't as well known or well accepted in the Russian academy, especially not in the context of the arguments you mount in relation to his work, and the synthesis you come up with.

Another late but valuable introduction to your formative forces is Weber, who represents mainstream sociology which is founded, as you say, on the primacy of social meaning but paradoxically makes no reference to linguistics as a discipline. On that fact I would point out that linguistics hardly existed when he wrote, certainly not in its more socially-orientated forms, like social semiotics. It would be reasonable I think to present your enterprise as among other things an attempt to fill the gap Weber faced, of a sociology built on meaning without any support from disciplines of language and meaning.

I felt that your account of Halliday's work was excessively positive, more suited to a 40-year anniversary than to a scholarly work, especially one with your aims for building a synthesis. You need to critique his limitations (which he surely has) as part of an argument for why other approaches need to be developed. You do touch on some significant ones, but you don't use them as the basis for your argument.

You could use SS [social semiotics] in Hodge and Kress as differentiated from Halliday to serve your argument. Kress and I were not seeking to attack Halliday, who was Kress's revered teacher, but as we made clear, we were seeking a clear break from Halliday's line of argument. Crucial in this was breaking with the connection with linguistics and the exclusive dominance of the verbal systems. Halliday was primarily a linguist (systemic functional) before and after his famous title, and his followers were mostly SF [systemic-functional] linguists, not social semioticians. In very recent times some scholars in that tradition have used social semiotics and the concept of multimodality to become slightly more aware of nonverbal codes, but they are still basically linguists. Your discussion of Halliday's equivocation with sociolinguistics could be used to make the point: that he did not manage a clear break from the limitations of the linguistics of his time.

Another concern we had with Halliday was the relative absence of social theory. He talked about it at times, but his theory and practice did not give it any content. That was why Kress and I had to go outside linguistics (and semiotics to a great extent, with a few honorable exceptions like Barthes) to Marxists, especially as you noted to the Russians Bakhtin and Vygotsky. 
What we didn't do, which you could develop further, is to go to Weber and sociology. And we didn't draw on Lotman, whose theories could be combined with some ideas from Weber as you could do. You mention some of these exciting ideas at various points, especially towards the end. They deserve a more careful and systematic presentation, over the article as a whole. I for one would love to read it. (Hodge 2019, personal communication)

Trying to take the comments into account, I sent to him a revised version. In the new critical remarks, which were taken into account in the recent version, Robert Hodge drew attention to a mistake I had made - Michael Halliday used the term 'social semiotic' and not the term 'social semiotics' which I had incorrectly attributed to him. Hodge wrote:

I attach a set of comments attached to your text. I hope you find them useful. The only one which I think is indispensable for you is the comment on the difference between Halliday's singular semiotic, and the plural semiotics, which may seem like only a letter different but is very different. (Hodge, letter to S. Z., 24 April 2019)

Actually, the term 'social semiotics' was introduced later, in Hodge, Kress 1988 but was not paid proper attention to. Thus, I asked for a clarification - how to understand and interpret this one-letter difference. I suggested that Hodge highlight the reasons for it - whether or not Halliday had been motivated by the Peircean term 'semeiotic', or if this difference might be interpreted as a grammatical one between a singular semiotic and various semiotics (in plural), or between 'semiotics' as a substantive and 'semiotic' as an attributive usage, and if the expression 'language as a social semiotic' could be understood in the attributive mode (something like: 'language as a social and semiotic entity'). In his answer, Hodge provided a detailed explanation, which reveals new significant aspects not only of the history of the term but also of the history of the discipline in general:

Dear Suren, Yes, you have got the basic point. 'Semiotic' is not the singular of 'semiotics', and 'semiotics' is not the plural of 'semiotic'. Both in fact are singular, and have widely different meanings. I apologise to you on behalf of anglophone writers, myself included, who do not take into account the difficulties, not signalled and often not fully conscious, that they imposed on the majority nonAnglo world. This is one of the worst cases I can think of. It is very complex, even for native English speakers. So much hangs on so little, though of course linguists and theorists delight in such things. 
Saussure coined 'semiology' as the new name for the new discipline he proposed, and in my view that was the right term. French also had the term 'semiotique', whose meaning was close enough to Halliday's 'semiotic', as a singular noun referring to a complex semiotic fact.

Halliday knew that he was creating a neologism for English, something he was fond of doing, and some might say that he did too often, though linguistic creativity in a linguistic innovator is hard to criticise. But he was not wanting to innovate a term for a new discipline. He had changed the name of his grammar (and hence implicitly his form of linguistics) from rank and scale to systemic functional linguistics, and the latter consolidated as the name he preferred for his disciplinary innovation.

The master category was linguistics. In the term social semiotic the main emphasis was on social, in that work, something that previous versions of his theory had not stressed so much. 'Semiotic' was there to emphasise the importance of meaning, something he believed had dropped out of linguistics, especially owing to the influence of Chomsky. But 'language', acknowledging other semiotic codes but always subordinated to verbal language, anchored the whole theory, which was an extended kind of linguistics, not the new discipline envisaged by Saussure (whose work Halliday knew very well, of course.)

'Social Semiotics' in Gunther and my book of 1988 signals its departure from Halliday's work with a sign so small that you may rightly criticise it for that fact. We wanted to depart from the dominant linguistics paradigm, which we felt constrained Halliday and most of his followers, but we wanted to maintain a respectful dialogue across this fundamental difference. Throughout his life we loved and revered Halliday himself, the man and his ideas which we believed were greater than the systems he proposed.

We hoped that with such a careful and tactful approach, exponents of SFL [systemic-functional linguistics] would quietly expand their horizons, and contribute to social semiotics. In my view, and I believe in Gunther's, what happened instead was a concerted effort by a politically powerful but intellectually impoverished group of academics to appropriate the term social semiotics and continue to elaborate their theory as a closed system.

That last judgement is of course merely my judgement, not a fact of the meaning of words or the progress of a discipline. Your own critique is important because it comes from outside the English language and the mentality it has created, which includes blindspots which English speakers do not see. I hope you will trust the validity of your own insights, and the wisdom contained in your own rich intellectual background, which includes some anglo-phones but also some intellectual giants from other languages and traditions. With good wishes to your thinking, Bob. (Hodge, letter to S. Z., 2 July 2019) ${ }^{12}$

12 Acknowledgment. The research for this article is supported by the Russian Science Foundation, project № 18-18-00442, "Mechanisms of meaning formation and textualization in social narrative and performative discourses and practices" in Im. Kant Baltic Federal University, Kaliningrad, Russia. 


\section{References}

Berger, Peter L.; Luckmann, Thomas 1966. The Social Construction of Reality: A Treatise in the Sociology of Knowledge. Garden City: Anchor Books.

Cobley, Paul; Randviir, Anti 2009. Introduction: What is sociosemiotics? Semiotica 173(1/4): $1-39$.

Firth, John Rupert 1957. Ethnographic analysis and language with reference to Malinovski's views. In: Firth, Raymond (ed.), Man and Culture: An Evaluation of the Work of Bronislaw Malinowski. London: Routledge \& Kegan Paul, 93-118.

Halliday, Michael A. K. 1978. Language as Social Semiotic: The Social Interpretation of Language and Meaning. Baltimore: University Park Press.

- 2009[1975]. Language as social semiotic: Towards a general sociolinguistic theory. In: Halliday, M. A. K., Collected Works. Vol. 10: Language and Society. (Webster, Jonathan J., ed.) London: Bloomsbury, 169-203.

Halliday, Michael A. K.; Ruqaiya, Hasan 1976. Cohesion in English. London: Longman.

Hjelmslev, Louis 1961[1943]. Prolegomena to a Theory of Language. Madison: University of Wisconsin Press.

Hodge, Robert; Kress, Gunther 1979. Language as Ideology. London: Routledge \& Kegan Paul.

- 1988. Social Semiotics. Ithaca: Polity, Cornell University Press.

Kress, Gunther (manuscript). Transposing meaning: Translation in a multimodal semiotic landscape.

Lindstrand, Fredrik 2008. Interview with Gunther Kress. Designs for Learning 1(2): 60-71.

Lotman, Juri 1975. Dekabrist v povsednevnoj zhizni (bytovoe povedenie kak istorikopsihologicheskaya kategoriya) [The Decembrist in everyday life (domestic conduct as a historical and psychological category)]. In: Bazanov, Vasilij G.; Vatsuro, Vadim E. (eds.), Literaturnoe nasledie dekabristov. Leningrad: Nauka, 25-74. [Лотман, Ю. М. 1975. Декабрист в повседневной жизни (бытовое поведение как историко-психологическая категория). In: Базанов, В. Г.; Вацуро, В. Э. (ред.), Литературное наследие декабристов. Ленинград: Наука, 25-74.]

- 1976. Bytovoye povedeniye i tipologiya kul'tury v Rossii XVIII v. [Everyday behavior and typology of culture in Russia in the 18th century.] In: Bazanov, Vasilij G. (ed.), Kul'turnoye naslediye drevney Rusi: Istoki. Stanovleniye. Traditsii. Moscow: Nauka, 292-297. [Лотман, Ю. М. 1976. Бытовое поведение и типология культуры в России XVIII в. In: Базанов, В. Г. (ред.), Культурное наследие древней Руси: Истоки. Становление. Традииии. Москва: Наука, 292-297.]

- 1977. Poetika bytovogo povedeniya v russkoj kul'ture XVIII veka [Poetics of everyday behaviour in Russian culture of the 18th century]. Sign Systems Studies 8: 65-69. [Лотман Ю. М. 1977. Поэтика бытового поведения в русской культуре XVIII века. Труды по знаковым системам $8: 65-69$.]

- 2005[1984]. On the semiosphere. (Clark, Wilma, trans.) Sign Systems Studies 33(1): 205229.

- 2008 [1988] Neskol'ko vvodnyh slov [A few introductory words]. Sign Systems Studies 36(2): 509-511. [Лотман, Юрий 2008. Несколько вводных слов Sign Systems Studies 36(2): 509-511.] 
- 2013. The Unpredictable Workings of Culture. Tallinn: Tallinn University Press.

Luhmann, Niklas 2012[1997]. Theory of Society. Vol. 1. (Barrett, Rhodes, trans.) Stanford: Stanford University Press.

- 2013[2002]. Introduction to Systems Theory. (Gilgen, Peter, trans.) Cambridge: Polity Press.

Malinowski, Bronislaw 1923. The problem of meaning in primitive languages. In: Ogden, Charles K.; Richards, Ivor A., The Meaning of Meaning: A Study of the Influence of Language upon Thought and of the Science of Symbolism. Supplement I. London: Kegan Paul, Trench, Trubner, 296-336.

- 1935. Coral Gardens and their Magic. Vol. 2: The Language of Magic and Gardening. London: Allen \& Unwin.

Morris, Charles 1964. Signification and Significance: A Study of the Relations of Signs and Values. Cambridge: The MIT Press.

Petrilli, Susan 2012. Social semiotics. In: Brown, Keith (ed.), Encyclopedia of Language and Linguistics. (2nd ed.) Elsevier Science, 458.

Searle, John R. 1995.The Construction of Social Reality. New York: Free Press.

- 2008. Language and social ontology. Theory and Society 37(5): 443-459.

Voloshinov, Valentin [Bakhtin, Mikhail] 1973[1929]. Marxism and the Philosophy of Language. (Matejka, Ladislav; Titunik, Irwin R., trans.) (Studies in Language.) New York: Seminar Press.

Weber, Max 1964[1947]. The Theory of Social and Economic Organization. New York: The Free Press.

Wittgenstein, Ludwig 1958 [1945-1949]. Philosophical Investigations. (Anscombe, Gertrude E. M., trans.) Oxford: Basil Blackwell.

Zolyan, Suren 2017. Yurij Lotman i sotsial'naya semiotika: K postanovke problemi. [Juri Lotman and social semiotics.] Zbornik matitse srpske za slavistiku [Matica Srpska Journal of Slavic Studies]; Славистический сборник - Review of Slavic Studies. Нови Сад.] Poselyagin, Nikolaj; Trunin, Mihail (eds.) Verba volant, scripta manent: Festshrift k 50-letiyu Igorya Pil'shchikova.] 92: 123-150. [Золян, Сурен 2017. Юрий Лотман и социальная семиотика: К постановке проблемы. Зборник матице српске за славистику (Matica Srpska Journal of Slavic Studies; Cлавистический сборник - Review of Slavic Studies. Нови Сад.) Поселягин, Николай; Трунин, Михаил (eds.), Verba volant, scripta manent: Фестирифт к 50-летию Игоря Пильщикова 92: 123-150.]

\section{Общая социолингвистика, социальная семиотика и семиотика культуры - ex pluribus unum? Сорок лет после книги «Язык как социальная семиотика»}

Резюме. Рождение социальной семиотики принято связывать с публикацией книги Майкла Хэллидея «Язык как социальная семиотика» (1978). Мы постаралиь привлечь внимание к новым возможным подходам в социальной семиотике, которые все еще остаются в стадии трансдисциплинарного проекта для социальных наук. В этих целях нами рассматривается взаимосвязь между социолингвистикой, социальной семиотикой 
и семиотикой культуры. Все они описывают выходящие за пределы языкового структурирования механизмы порождения и передачи смысла. Различия между ними основываются на различии между различными аспектами смыслопорождения и коммуникации и функциональными характеристиками коммуникативного целеполагания. Сложность этих процессов оправдывает сложность методологии их описания. Взаимосвязь между различными областями и аспектами может создавать синтетические методы, основанные на динамическом подходе к порождению и передаче смысла.

\section{Üldine sotsiolingvistika, sotsiosemiootika ja kultuurisemiootika - ex pluribus unum? Nelikümmend aastat raamatut „Keel sotsiaalse semiootikana“}

Sotsiosemiootika sündi seostatakse tavaliselt Michael Halliday raamatu „Keel sotsiaalse semiootikana“ (1978) avaldamisega. Püüame juhtida tähelepanu võimalikele uutele arengutele sotsiosemiootikas, mis sotsiaalteaduste jaoks jäävad siiski potentsiaalseks transdistsiplinaarseks projektiks. Et seda teha, käsitleme sotsiolingvistika, sotsiosemiootika ning kultuurisemiootika omavahelist suhet. Kõik need kirjeldavad tähendusloome ja tõlke lingvistilistest struktuuridest kaugemale jäävaid mehhanisme. Nende eristamine põhineb eristusel mitmesuguste tähendusloome ja kommunikatsiooni aspektide ning eesmärgiseade funktstionaalsete omaduste vahel. Nende protsesside keerukus legitimeerib nende kirjeldamiseks kasutatava metoodika komplekssust. Erinevate valdkondade ja aspektide vaheline seos võib luua sünteetilisi meetodeid, mis põhinevad dünaamilisel lähenemisel tähenduse loomisele ja edastamisele. 